\title{
Analisis Regresi Ordinal Atas Pemahaman Wajib Pajak Orang Pribadi Mengenai Pajak Penghasilan
}

\author{
Titin Vegirawati ${ }^{1}$, Mas Amah ${ }^{2}$, Hadli $^{3}$ \\ ${ }^{1}$ Akuntansi, Fakultas Ekonomi Universitas IBA Palembang, titinvegirawati@gmail.com \\ ${ }^{2}$ Akuntansi, Fakultas Ekonomi Universitas IBA Palembang \\ ${ }^{3}$ Akuntansi, Fakultas Ekonomi Universitas IBA Palembang
}

\begin{abstract}
ABSTRAK
Pajak penghasilan merupakan salah satu penerimaan negara terbesar.Sebagian besar wajib pajak yang membayar pajak penghasilan adalah wajib pajak orang pribadi.Untuk memicu wajib pajak membayar pajak, wajib pajak harus memahami pajak penghasilan, yang meliputi makna dan peraturan dan perundang-undangan pajak penghasilan.Ada beberapa faktor karakteristik wajib pajak yang mempengaruhi pemahaman wajib pajak terhadap pajak penghasilan, yang terdiri dari gender, tingkat pendidikan dan tingkat penghasilan.Penelitian ini menggunakan kuisioner sebagai alat pengumpulan data primernya.Teknik penarikan sampel yang digunakan adalah simple random sampling dengan jumlah sampel 100 orang wajib pajak orang pribadi.Alat analisis yang digunakan adalah regresi ordinal logistic. Hasil penelitian menunjukkan bahwa model penelitian ini cocok dan secara simultan ketiga variabel prediktor mampu menjelaskan pemahaman wajib pajak terhadap pajak penghasilan sebagai variabel respon.
\end{abstract}

Kata Kunci: Gender, Tingkat Pendidikan, Tingkat Pendapatan, Pajak Penghasilan.

\begin{abstract}
Income tax is one of the largest state revenues. Most taxpayers who pay income tax are individual taxpayers. To trigger taxpayers to pay taxes, taxpayers must understand income tax, which includes the meaning and regulations and income tax legislation. There are several factors characteristic of taxpayers that affect taxpayers' understanding of income tax, which consists of gender, education level and income level. This study uses a questionnaire as a primary data collection tool. The sampling technique used was simple random sampling with a sample of 100 individual taxpayers. The analytical tool used is ordinal logistic regression. The results showed that this research model was suitable and simultaneously the three predictor variables were able to explain the taxpayer understanding of income tax as a response variable.
\end{abstract}

Keywords: Gender, Education Level, Income Level, Income Tax.

\section{A. PENDAHULUAN}

Pemerintah membutuhkan

sumber dana untuk menjalankan fungsinya. Salah satu sumber dana utama pemerintah adalah pajak.Pemerintah dapat memaksakan pajak kepada rakyatnya tanpa memberikan imbalan langsung.Pajak dapat dipungut melalui wajib pajak orang pribadi maupun wajib pajak badan.

Berbagai upaya yang dilakukan pemerintah untuk mendorong masyarakat untuk taat membayar pajak.System pelaporan Self Assessment masih tetap dipertahankan mulai dari tahun 1983 sampai saat ini.Dengan system ini masyarakat diberikan hak untuk mendaftarkan diri sebagai wajib pajak, menghitung, menyetorkan serta melaporkan jumlah pajak yang harus dibayar.(Nugraheni \& Purwanto, 2015) Kepatuhan membayar pajak ditentukan oleh kesadaran wajib pajak dalam mematuhi aturan 
perpajakan.Menurut (Fitria, 2017) seorang wajib pajak mempunyai kesadaran apabila:

1. Mengetahui bahwa ada undangundang dan peraturan perpajakan

2. Fungsi pajak adalah untuk membiayai kebutuhan Negara

3. Bersedia menghitung, membayar dan melaporkan utang pajak secara benar dan sukarela.

Masih rendahnya kesadaran
wajib pajak dapat disebabkan
rendahnya pemahaman wajib pajak
mengenai peraturan perundang-
undangan perpajakan.Padahal
pemahaman mengenai peraturan
perundang-undangan perpajakan
memudahkan wajib pajak untuk
menghitung, membayar dan melaporkan kewajiban perpajakannya. Rendahnya pengetahuan justru akan menyebabkan ketakutan wajib pajak terhadap kewajiban perpajakannya, sehingga menimbulkan keengganan patuh membayar pajak.

Jika dibandingkan, jumlah wajib pajak orang pribadi yang ada di Indonesia pada tahun 2020 jauh lebih banyak dibandingkan wajib pajak badan. NPWP pribadi berjumlah 38,7 juta, sementara jumlah NPWP badan hanya 3,3 juta wajib pajak. Sehingga penelitian mengenai wajib pajak orang pribadi menjadi sangat penting.

Pemahaman wajib pajak orang pribadi menjadi suatu keharusan untuk menjadikan wajib pajak patuh terhadap peraturan dan atau perundangundangan perpajakan. Pemahaman dijelaskan secara gambling dalam Theory of Understanding(Campbell, 1982). Dalam teori ini, pemahaman bukan ditentukan oleh subjek materi yang akan dipahami saja, tetapi juga berdampak sebab akibat dengan sikap proporsional untuk memahami secara perilaku. Pemahaman merupakan sebuah perilaku yang diwarnai oleh keyakinan subjek dan keinginan terhadap subjek pemahaman tersebut.

Hal serupa terjadi juga pada wajib pajak orang pribadi dalam memahami peraturan perundangundangan perpajakan.Pemahaman seseorang tidak hanya ditentukan oleh materi peraturan perundang-undangan mengenai pajak penghasilan, tetapi juga karakteristik pribadi yang membentuk keyakinan dan keinginan terhadap subjek tersebut.

Beberapa penelitian(Setiawati \& Arsana , 2018; Sandora, 2018) dan yang meneliti pengaruh gender terhadap pemahaman suatu ilmu telah dilakukan. Hasil penelitian menunjukkan hasil yang berbeda. Penelitian Setiawati dan Arsana (2018) menjelaskan bahwa ada pengaruh gender dalam memahami pengetahuan. Sementara Arsana menjelaskan bahwa tidak ada pengaruh gender dalam memahami pengetahuan.

Seseorang yang menjadi wajib pajak mempunyai latar belakang pendidikan yang berbeda-beda.Tingkat pendidikan yang berbeda menyebabkan sikap dan keinginan yang berbeda dalam memahami sebuah pengetahunan.Salah satu penelitian yang meneliti pengaruh tingkat pendidikan dalam memahami pengetahuan dilakukan oleh (Yasin, 2004). Hasil penelitian ini menjelaskan bahwa terdapat pengaruh pendidikan terhadap pemahaman pada level pendidikan menengah dan tinggi.

$$
\text { Pajak dikenakan atas }
$$
penghasilan seseorang.Semakin besar jumlah penghasilannya, maka semakin tinggi pajak yang harus dibayar wajib pajak tersebut.Oleh karena itu seharusnya seseorang yang mempunyai penghasilan yang tinggi berkeinginan untuk memahami pajak penghasilan.Salah satu penelitian yang 
dilakukan oleh (Suryanto \& Rasmini , 2018) meneliti mengenai pengaruh umur, pendidikan dan tingkat pendapatan terhadap pemahaman pengetahuan keuangan.Hasil penelitian mereka menunjukkan pendidikan formal dan tingkat pendapatan mempengaruhi pemahaman pengetahuan tersebut.

\section{B. KAJIAN TEORI}

\section{1) Theory of Understanding}

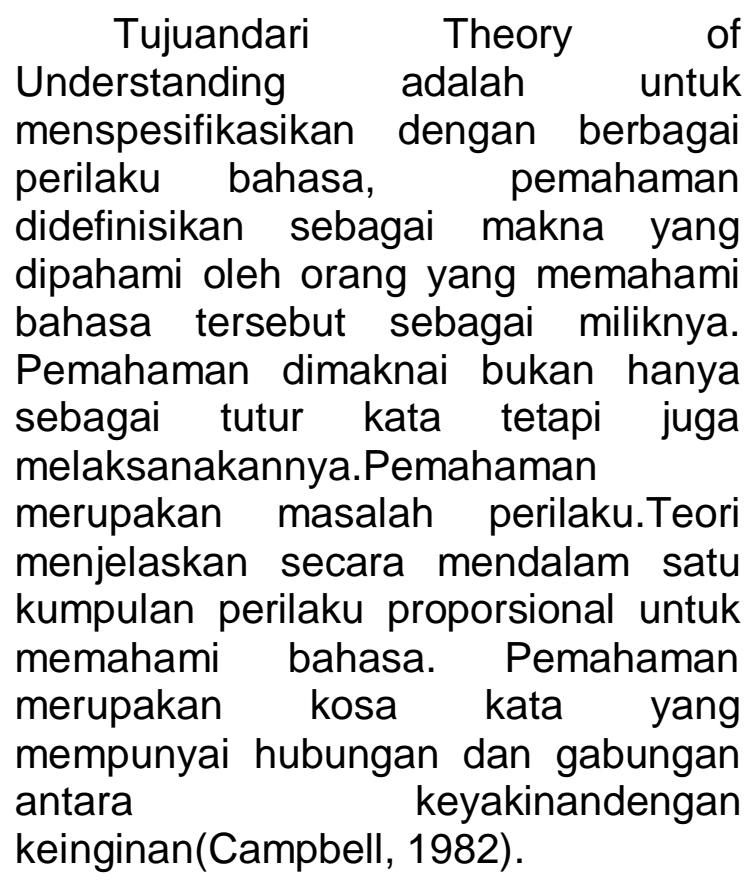

\section{2) Pengetahuan Wajib Pajak mengenai Pajak Penghasilan}

Pajak Penghasilan merupakan pajak yang dikenakan atas penghasilan.Subjek pajak ini adalah orang pribadi atau badan.Sementara objek pajaknya adalah penghasilan.Penghasilan yang diperoleh oleh wajib pajak orang pribadi meliputi upah dan gaji, pendapatan atas modal yang berupa capital gain dan dividen, atau pendapatan dari bunga. Sementara penghasilan dari wajib pajak badan berupa penghasilan perusahaan dan atau keuntungan (Suratman, 2009).
Dalam memenuhi kewajiban pembayaran pajak penghasilan, wajib pajak harus memahami pajak penghasilan yang sudah diatur dalam Undang-undang nomor 36 tahun 2008 tentang perubahan keempat atas Undang-undang nomor 7 tahun 1983 tentang Pajak Penghasilan. Undang undang tersebut membahas mengenai Ketentuan Umum Undang-undang Pajak Penghasilan.Subjek Pajak Penghasilan, Objek Pajak Penghasilan, cara menghitung penghasilan kena pajak dan besarnya penghasilan tidak kena pajak, ketentuan lain dan ketentuan penutup

Besar Penghasilan Tidak kena Pajak terus mengalami perubahan.Peraturan terbaru mengenai besarnya PTKP diatur oleh PMK nomor 101/ PMK nomor 010/tahun 2016. Pasal 17 Ayat 1 Huruf a Undang-Undang Republik Indonesia Nomor 26 Tahun 2008. Secara sederhana, tarif yang diberlakukan adalah $5 \%, 15 \%, 25 \%$, dan $30 \%$ untuk wajib pajak yang memiliki NPWP. Sedangkan untuk wajib pajak tanpa NPWP tarifnya $20 \%$ lebih tinggi.

\section{3) Penelitian Terdahulu}

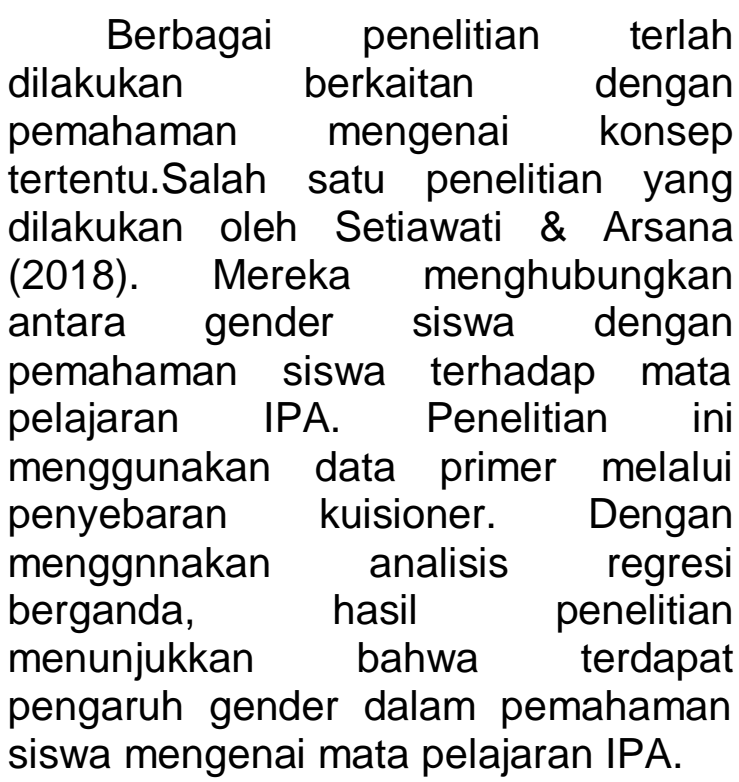


Penelitian lain yang dilakukan oleh (agustina \& Yanti, 2015). Penelitian ini mengamati faktor-faktor yang mempengaruhi pemahaman mahasiswa akuntansi. Faktor-faktor yang merupakan variabel independen adalah latar belakang pendidikan mahasiswa tersebut. Penelitian menggunakan kuisioner dalam mengambil data 149 mahasiswa. Dengan analisis berganda diperoleh hasil bahwa latar belakang pendidikan berpengaruh terhadap pemahaman mahasiswa akuntansi.

Suryanto \& Rasmini(2018) melakukan penelitian mengenai pemahaman literasi keuangan. Penelitian ini meneliti perusahaan mikro kecil dan menengah yang ada di kota Bandung. Penelitian ini menggunakan data kuisioner.Penelitian ini menggunakan sampel kecil yaitu sebesar 30 responden. Dengan menggunakan analisis regresi berganda peneliti menemukan adanya pengaruh tingkat pendapatan terhadap literasi keuangan mereka.

\section{4) Hipotesis Penelitian}

Dari kajian teori yang telah dikemukakan mengenai Theory of Understanding dan beberapa penelitian yang telah dilakukan oleh berbagai peneliti maka dapat digambarkan kerangka pemikiran dalam penelitian ini yaitu:
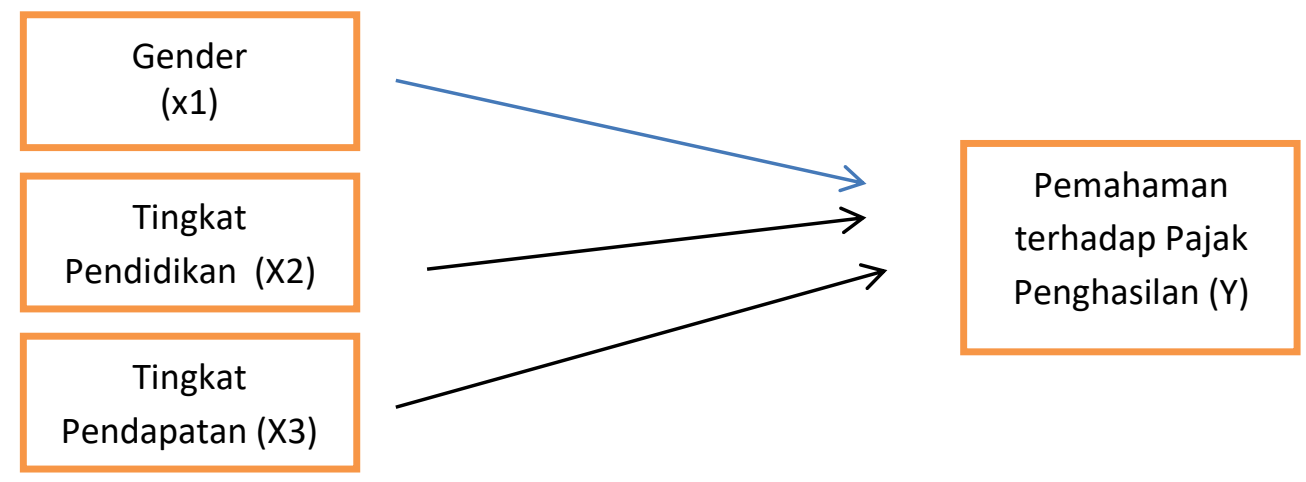

Gambar Kerangka Pemikiran

Dari kerangka pemikiran tersebut dapat dirumuskan hipotesis penelitian:

Variabel gender, tingkat
pendidikan dan tingkat
pendapatan mempengaruhi
pemahanan wajib pajak terhadap
pajak penghasilan.

\section{METODE PENELITIAN}

1) Populasi dan Sampel

Penelitian ini memilih wajib pajak orang pribadi yang terdaftar di KPP Pratama llir Barat yang ada di Kecamatan Bukit Kecil Palembang sebagai populasi. Jumlah wajib pajak orang pribadi yang terdaftar pada KPP
Pratama llir Barat adalah 130.864 orang.Sampel penelitian dipilih dengan menggunakan metode Simple Random Sampling.Metode ini dipilih dengan tujuan agar semua anggota populasi mendapatkan hak untuk dipilih sebagai anggota sampel.

\section{2) Variabel Penelitian}

Variable penelitian yang digunakan dalam penelitian ini adalah variable respon dan variable prediktor

\section{$>\quad$ Variabel Respon}

Variabel respon dalam penelitian ini adalah pemahaman wajib 
pajak mengenai pajak penghasilan.

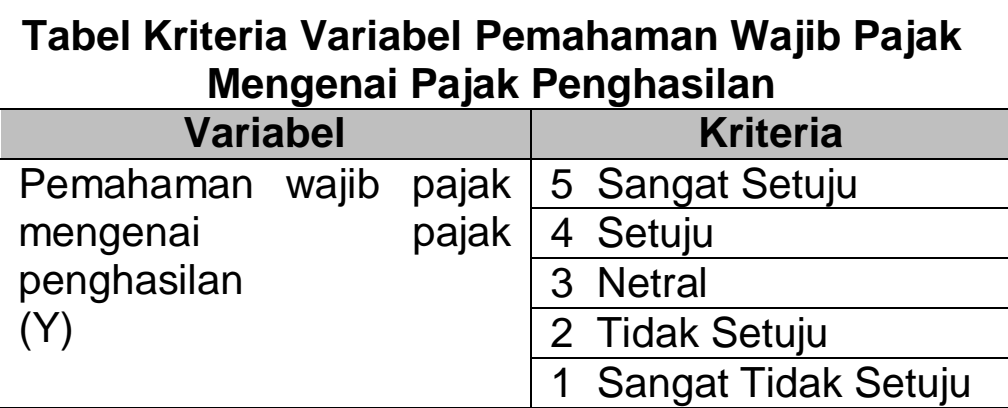

Sumber : Peneliti

Variabel Prediktor

Variabel Prediktor dalam penelitian ini adalah adalah karakteristik wajib pajak orang pribadi yang terdiri dari gender, pendidikan dan pendapatan wajib pajak.

Tabel Kriteria Variabel Gender $\left(\mathrm{X}_{1}\right)$ Pendidikan $\left(\mathrm{X}_{2}\right)$ dan Pendapatan $\left(\mathrm{X}_{3}\right)$

\begin{tabular}{|l|l|}
\hline \multicolumn{1}{|c|}{ Variabel } & \multicolumn{1}{c|}{ Kriteria } \\
\hline Jenis Kelamin (X1) & 1. Laki-laki \\
& 2. Perempuan \\
\hline Pendidikan (X2) & 1 SMA \\
& 2 Diploma III \\
& 3 S1 \\
& 4 Pasca Sarjana \\
\hline Pendapatan (X3) & 1 <p 3.000.000 \\
& 2 Rp 3.000.000-4.000.000 \\
& 3 Rp 4.000.000-Rp 5.000.000 \\
& 4 Rp 5.000.000 \\
\hline
\end{tabular}

Sumber : Peneliti

3) Analisis Kualitas Data

a) Uji Validitas

Validitas merupakan suatu indeks yang menunjukkan alat ukur tersebut mengukur apa yang ingin diukur ( $E, 2011)$. Pengujian validitas menggunakan SPSS dengan mengbandingkan koefisien product moment atas skor butir pertanyaan dengan skor total.Jika nilai koefisien lebih besar dari $r$ tabel sebesar 0,3 maka, butir pertanyaan tersebut dinyatakan valid. b) Uji Reliabilitas

Uji reliabilitas merupakan indeks yang mengukur keandalan alat ukur tersebut (E, 2011). Uji reliabilitas variable respon menggunakan koefisien cronbach's alpha, berdasarkan kriteria batas reliabilitas adalah sebesar 0,6 dengan nilai alpha 0.05

\section{4) Metode Analisis Data}

Metode analisis data yang digunakan adalah metode regresi 
ordinal logistic. Metode ini sangat cocok digunakan karena variable respomdalam penelitian ini berskala ordinal, sementara variable prediktornya dapat berskala nominal atau kategorik, ordinal dan interval (indahwati, Kusumaningrum, \& Maena , 2010). Analisis dilakukan dengan melakukan uji kesesuaian model, uji simultanmenghitung koefisien determinasi model dengan menggunakan Mc Fadden, Cox and Snell dan Nagelkerke $R$ Square, dan uji parsial

\section{HASIL PENELITIAN \\ 1) Profil Responden}

Penelitian dilakukan terhadap 100 responden yang merupakan wajib pajak orang pribadi yang terdaftar pada KPP Pratama Ilir Barat. Karakteristik Responden tersebut disajikan pada tabel berikut:

TabelData Statistik Responden

\begin{tabular}{|c|c|c|c|}
\hline \multirow{2}{*}{ Jenis Kelamin } & Pria & 45 & $45 \%$ \\
\cline { 2 - 4 } & Wanita & 55 & $55 \%$ \\
\hline \multirow{3}{*}{ Umur } & Kurang dari 20 tahun & 4 & $4 \%$ \\
\cline { 2 - 4 } & $21-30$ tahun & 65 & $65 \%$ \\
\cline { 2 - 4 } & $31-40$ tahun & 15 & $15 \%$ \\
\hline \multirow{3}{*}{ Status } & $41-50$ tahun & 16 & $16 \%$ \\
\hline \multirow{3}{*}{ Perkawinan } & Menikah & 63 & $63 \%$ \\
\cline { 2 - 4 } & Tidak Menikah & 37 & $37 \%$ \\
\cline { 2 - 4 } & SMA & 35 & $35 \%$ \\
\cline { 2 - 4 } & D3 & 21 & $21 \%$ \\
\cline { 2 - 4 } & Sarjana & 40 & $40 \%$ \\
\hline \multirow{3}{*}{ Pendapatan } & Pascasarjana & 35 & $4 \%$ \\
\cline { 2 - 4 } & Rp 3.000.000-Rp 4.000.000 & 31 & $35 \%$ \\
\cline { 2 - 4 } & Rp 4.000.000 -Rp 5.000.000 & 16 & $16 \%$ \\
\cline { 2 - 4 } & $>$ Rp 5.000.000 & 18 & $18 \%$ \\
\hline
\end{tabular}

Sumber : data diolah

\section{2) Hasil Uji Validitas}

Hasil uji validitas dapat dilihat pada tabel berikut:

Tabel Hasil Uji Validitas Variabel Pemahaman Wajib Pajak atas Pajak Penghasilan

$\mathrm{n}=100, \alpha=10 \%, r$ tabel $=0,30$

\begin{tabular}{|l|c|c|c|}
\hline \multicolumn{1}{|c|}{$\begin{array}{c}\text { Butir } \\
\text { Pernyataan }\end{array}$} & $\mathbf{r}_{\text {hitung }}$ & $\mathbf{r}_{\text {tabel }}$ & Keterangan \\
\hline Pernyataan 1 & 0,548 & 0,3 & Valid \\
\hline Pernyataan 2 & 0,579 & 0,3 & Valid \\
\hline Pernyataan 3 & 0,586 & 0,3 & Valid \\
\hline Pernyataan 4 & 0,568 & 0,3 & Valid \\
\hline Pernyataan 5 & 0,537 & 0,3 & Valid \\
\hline Pernyataan 6 & 0,517 & 0,3 & Valid \\
\hline
\end{tabular}




\begin{tabular}{|l|l|l|l|}
\hline Pernyataan 7 & 0,567 & 0,3 & Valid \\
\hline Pernyataan 8 & 0,461 & 0,3 & Valid \\
\hline Pernyataan 9 & 0,423 & 0,3 & Valid \\
\hline Pernyataan 10 & 0,447 & 0,3 & Valid \\
\hline Pernyataan 11 & 0,526 & 0,3 & Valid \\
\hline Pernyataan 12 & 0,538 & 0,3 & Valid \\
\hline Pernyataan 13 & 0,476 & 0,3 & Valid \\
\hline Pernyataan 14 & 0,401 & 0,3 & Valid \\
\hline Pernyataan 15 & 0,415 & 0,3 & Valid \\
\hline Pernyataan 16 & 0,519 & 0,3 & Valid \\
\hline Pernyataan 17 & 0,392 & 0,3 & Valid \\
\hline
\end{tabular}

\section{Sumber : data diolah}

Dari hasil analisis yang ditunjukkan dalam tabel tersebut, menunjukkan koefisien item dengan total item lebih besar dari 0,30. Hal ini menunjukkan bahwa semua item pernyataan pada variable respon valid.

\section{3) Hasil Uji Reliabilitas}

Hasil Uji reliabilitas variabel respon dalam penelitian ini dapat dilihat pada tabel berikut:

\section{Tabel Hasil Uji Reliabilitas}

\begin{tabular}{|c|c|}
\hline $\begin{array}{c}\text { Cronbach's } \\
\text { Alpha }\end{array}$ & N of ltems \\
\hline 0.812 & 17 \\
\hline
\end{tabular}

\section{Sumber : Hasil analisis}

Hasil uji reliabilitas variabel respon pengetahuan atas Undang- undang Pajak Penghasilan menunjukkan bahwa nilai cronbach alpha adalah sebesar 0,812 lebih besar dari 0,6, sehingga dapat dikatakan bahwa reliabel

\section{4) Uji Hipotesis}

Analisis data dilakukan dengan menggunakan teknik analisis regresi logistik ordinal.Alat analisis ini digunakan karena variabel respon dalam model penelitian ini berskala ordinal, sementara variabel prediktornya terdiri dari data berskala nominal dan interval.

\section{Uji Simultan}

Hasil analisis uji simultan atas variabel prediktor terhadap variabel respon dapat dilihat pada tabel berikut:

Tabel Model Fitting Information

\begin{tabular}{|l|r|r|r|r|}
\hline \multicolumn{1}{|c|}{ Model } & $\mathbf{- 2}$ Log Likelihood & Chi-Square & df & \multicolumn{1}{c|}{ Sig } \\
\hline $\begin{array}{l}\text { Intercept } \\
\text { Only }\end{array}$ & 511.701 & & & \\
\hline Final & 498.970 & 12.731 & 5 & .026 \\
\hline
\end{tabular}

Sumber: Hasil Analisis

Berdasarkan hasil uji simultan, maka diperoleh nilai Chi-square sebesar 12,731 dan nilai $p$-value sebesar 0.026 . Maka keputusan yang diambil adalah menolak $\mathrm{H}_{0}$ karena nilai $\mathrm{p}$-value < dari $\alpha$. Dengan demikian dapat dikatakan bahwa dengan tingkat keyakinan $95 \%$ dapat dikatakan bahwa model dengan menggunakan variabel prediktor lebih baik dari tidak menggunakan variabel prediktor. 
Uji Kecocokan Model (Goodness of Fit)

Untuk menguji kecocokan model dalam analisis regresi logistik, dapat menggunakan hasil Goodness of Fit. Hasil uji kecocokan model dapat dilihat pada tabel berikut:

Tabel Goodness of Fit

\begin{tabular}{|l|r|r|r|}
\hline & Chi-Square & \multicolumn{1}{c|}{ df } & \multicolumn{1}{c|}{ Sig. } \\
\hline Pearson & 953.273 & 940 & .374 \\
\hline Deviance & 395.357 & 940 & 1.000 \\
\hline
\end{tabular}

Sumber: Hasil Analisis

Berdasarkan uji kecocokan model diperoleh nilai Chi-Square uji Pesrson adalah 953,273 dan nilai p-value sebesar 0,374 dan nilai chi-square uji deviance adalah sebesar 395,357 dan $p$-value adalah 1,000. Karena nilai $p$ value lebih besar dari a sebesar 0,05, maka dapat dikatakan bahwa model regresi yang digunakan cocok.

\section{$>$ Koefisien Determinasi Model}

Hasil perhitungan koefisien determinasi model dapat dilihat pada tabel berikut:

\section{Tabel Pseudo R-Square}

\begin{tabular}{|l|l|}
\hline Cox and Snell & .120 \\
\hline Nagelkerke & .120 \\
\hline McFadden & .019 \\
\hline
\end{tabular}

Sumber: Hasil Analisis
Koefisien Determinasi dalam model regresi logistik ditunjukkan oleh nilai cox and Snell, Nagelkerke dan nilai McFadden.Koefisien determinasi pada hasil penelitian ini menggunakan nilai Nagelkerge, yaitu sebesar 0,120.Nilai ini menunjukkan bahwa semua variabel prediktor mampu menjelaskan variabel respon sebesar $12 \%$. Sementara nilai sisanya sebesar $88 \%$ dapat dijelaskan oleh variabel lain yang tidak diteliti dalam penelitian ini.

\section{$>\quad$ Uji Parsial}

Hasil uji parsial ditunjukkan pada tabel berikut:

TabelParameter Estimates

\begin{tabular}{|r|l|r|l|r|r|r|r|r|}
\hline \multicolumn{2}{|c|}{} & Estimate & $\begin{array}{l}\text { Std } \\
\text { Error }\end{array}$ & Wald & df & Sig & \multicolumn{2}{|l|}{$\begin{array}{l}\text { 95\% Confidence } \\
\text { Internal }\end{array}$} \\
\cline { 4 - 10 } & & & & & & $\begin{array}{l}\text { Lower } \\
\text { Bound }\end{array}$ & $\begin{array}{l}\text { Upper } \\
\text { Bound }\end{array}$ \\
\hline Location & Income & .441 & .162 & 7.372 & 1 & .007 & .123 & .759 \\
\hline & {$[$ Sex=1] } & -.124 & .370 & .112 & 1 & .738 & -.848 & .601 \\
\hline & {$[$ Sex=2] } & $0^{\mathrm{a}}$ &. &. & 0 &. &. &. \\
\hline & {$[\mathrm{Edu}=1]$} & .216 & .979 & .049 & 1 & .825 & -1.702 & 2.134 \\
\hline & {$[\mathrm{Edu}=2]$} & -.447 & .972 & .211 & 1 & .646 & -2.353 & 1.459 \\
\hline & {$[\mathrm{Edu}=3]$} & -.766 & .946 & .656 & 1 & .418 & -2.620 & 1.088 \\
\hline & {$[\mathrm{Edu}=4]$} & $0^{\mathrm{a}}$ &. &. & 0 &. &. & .759 \\
\hline
\end{tabular}

Sumber: Hasil Analisis 
Hasil output pada pada uji parsial menunjukkan bahwa nilai $p$-value pada variabel pendapatan adalah 0,007 lebih kecil dari nilai $\alpha$, sehingga variabel pendapatan $\left(X_{3}\right)$ berpengaruh secara signifikan terhadap pemahaman wajib pajak pada pajak penghasilansebagai variabel respon. Hasil analisis ini juga membuktikan bahwa nilai $p$-value variabel gender dan variabel tingkat pendidikan adalah 0,738 dan 0,825 lebih besar dari 0.05. Hasil ini menunjukkan bahwa secara parsial kedua variabel tersebut tidak mempunyai pengaruh signifikan terhadap pemahaman wajib pajak terhadap pajak penghasilan.

\section{E. PEMBAHASAN}

Hasil penelitian mengenai pengaruh gender, tingkat pendidikan dan pendapatan terhadap pemahamn wajib pajak mengenai pajak penghasilan yang dianalisis dengan menggunakan analisis regresi logistic menunjukkan pengaruh yang positif dan signifikan. Hasil ini menunjukkan bahwa makin besar nilai ketiga variabel prediktor maka semakin tinggi tingkat pemahaman wajib pajak mengenai pajak penghasilan. Hasil penelitian ini juga mendukung theory of understanding yang menjelaskan bahwa peningkatan pemahaman juga dibangun oleh sikap perilaku masingmasing wajib pajak.

Hasil penelitian menunjukkan pengaruh signifikan, dengan koefisien determinasi yang kecil.Ini menunjukkan bahwa 12 persen perubahan variabel pemahaman wajib pajak atas pajak penghasilan dipengaruhi oleh karakteristik wajib pajak yaitu gender, tingkat pendidikan dan income. Sementara 88 persen dipengaruhi oleh variabel lain yang tidak diteliti dalam penelitian ini. Variabel tersebut antara lain adalah variabel eksternal dari diri orang tersebut, misalnya dipengaruhi oleh pendidik atau orang lain yang memberikan pemahaman (utomo , Imron, \& M, 2017). Variabel yang lain yang mungkin mempengaruhi pemahaman wajib pajak terhadap pajak penghasilan adalah sosialisasi pajak, seperti yang dinyatakan oleh hasil penelitian yang dilakukan pada wajib pajak di Malang (Pekerti, 2015)

Hasil uji parsial penelitian ini menunjukkan bahwa hanya variabel pendapatan yang berpengaruh secara signifikan terhadap pemahaman wajib pajak terhadap pajak penghasilan. Hal ini sejalan dengan Theory of Understanding. Seseorang yang memiliki penghasilan yang tinggi akan dikenakan pajak. Maka keinginannya untuk memahami pajak penghasilan menjadi semakin tinggi.Hasil penelitian ini juga sejalan dengan penelitian yang dilakukan oleh Suryanto dan Rasmini (2018), bahwa seseorang yang memiliki pendapatan yang tinggi, literasi keuangannya juga baik. Pemahaman terhadap pajak penghasilan juga merupakan salah satu cara mengelola jumlah uang yang wajib dikeluarkan.

Secara parsial variabel gender terbukti tidak memiliki pengaruh yang signifikan terhadap pemahaman wajib pajak mengenai penghasilan. Hasil penelitian ini bertentangan dengan hasil penelitian yang dilakukan oleh Setiawati dan Arsana (2018), yang menyatakan bahwa gender berpengaruh terhadap pemahaman pembelajaran.

Variabel pendidikan dalam penelitian ini secara parsial terbukti secara empiris tidak mamapu menjelaskan perubahan pemahaman wajib pajak mengenai pajak penghasilan. Hasil penelitian ini bertentangan dengan hasil penelitian yang dilakukan oleh Agustina dan 
Yanti (2015). Hal ini terjadi kemungkinan disebabkan pendidikan yang lebih tinggi tidak selalu berdampak pada peningkatan kewajiban membayar pajak.

\section{F. KESIMPULAN DAN SARAN \\ 1) Kesimpulan}

Hasil penelitian terhadap 100 orang sampel wajib pajak orang pribadi di KPP Pratama Ilir Barat menunjukkan bahwa :

a. Terdapat pengaruh signifikan gender, tingkat pendidikan dan tingkat income terhadap pemahaman wajib pajak mengenai pajak penghasilan

b. Secara parsial dari tiga variable penelitian, hanya variable tingkat pendapatan yang mempunyai pengaruh signifikan terhadap pemahaman mengenai pajak penghasilan

\section{2) Saran}

a. Pemerintah melalui KPP harus mengupayakan meningkatkan pendidikan dan tingkat pendapatan wajib pajak agar wajib pajak memahami mengenai pajak penghasilan.

b. Pengaruh yang kecil antara variable gender, tingkat pendidikan dan tingkat income mendorong peneliti lain untuk menambah variable-variabel independen lain untuk diteliti, seperti variabel eksternal wajib pajak yang meliputi variabel sosialisasi pajak penghasilan dan instruktur pembelajaran pajak penghasilan.

\section{DAFTAR PUSTAKA}

Afifi, H. J. (2017). Faktor-Faktor yang Memengaruhi Wajib Pajak melakukan Tax Planning. Yogyakarta: Universitas Muhammadiyah .

agustina, \& Yanti, D. (2015). Analisis Faktor-faktor yang Mempengaruhi Tingkat Pemahanan Akuntansi

Mahasiswa Jurusan Akuntasi STIE MIKROSKIL MEDAN. Jurnal Wira Ekonomi Mikroskil, 5(01), 11-19.

Campbell, J. (1982). Knowledge and Understanding. Philosophical Quarterly, 32(126), 17-34.

E, R. (2011). Uji Validitas dan Reliabilitas Dalam Penelitian Epidemologi Kedokteran Gigi. Stomatognatic, 8(1), 27-34.

Fitria, D. (2017). Pengaruh Kesadaran Wajib Pajak, Pengetahuan dan Pemahaman Perpajakan Terhadap Kepatuhan Wajib Pajak. Journal of Applied Business and Economics, 4(1), 30-44.

Handayaningrum, \& Hendaris, R. (2011). Analisis Permasalahan Wajib Pajak Orang Pribadi dalam Memenuhi Kewajiban Perpajakannya. Portofolio Vol. 8 No. 2, 1-20.

indahwati, Kusumaningrum, D., \& Maena , I. (2010). Aplikasi Regresi Logistik Ordinal Multilevel Untuk Pemodelan dan Kladifikasi Huruf Mutu Mata Kuliah Metoda Statistika. Forum Statistika dan Komputasi, 15(2), 23-31.

Nanda, Y., Arfan, T., \& Zifi, M. P. (2017). Tax Planning pada Pajak Penghasilan Pasal 21 bagi Wajib Pajak Orang Pribadi Suami Istri yang Memiliki Penghasilan 
Masing-masing. Jurnal Akuntansi Keuangan dan Bisnis Vol. 10, No. 2, 44-50.

Nugraheni, A., \& Purwanto, A. (2015). Faktor-faktor yang

Mempengaruhi Kepatuhan Wajib Pajak Orang Pribadi. Diponegoro Journal of Accounting, 4(3), 1-14.

Pekerti, T. C. (2015). Pengaruh Sosialisasi Perpajakan terhadap Pemahaman Wajib Pajak yang Mendukung Kepatuhan Wajib Pajak. Jurnal Perpajakan, 7(1), 110.

sandora, L. (2018). Pengaruh Sikap dan Gender terhadap Prestasi Belajar Psikologi Mahasiswa Universitas Islam Imam Bonjol Padang. Menara IImu, 12(3), 8690.

Setiawati, G., \& Arsana , A. (2018). Pengaruh Motivasi Belajar dan Gender Terhadap Prestasi Belajar IPA Siswa Kelas Bilingual SMP (SLUB) Saraswati 1 Denpasar. Proceeding Biology
Education Conference, 15(1), 173-179.

Suratman, E. (2009). Pengaruh Pajak Penghasilan terhadap Kesejahteraan: Suatu Model Teoritis. Jurnal Ekonomi Pembangunan, 10(1), 125-137.

Suryanto, \& Rasmini , M. (2018). Analisis Literasi Keuangan dan Faktor-faktor yang Mempengaruhinya. Jurnal IImu Politik dan Komunikasi, 8(2), 118.

utomo , A., Imron, A., \& M, S. (2017). Pengaruh Penjelasan Guru Terhadap Pemahaman Siswa pada Mata Pelajaran Sejarah. Jurnal FKIP UNILA.

Yasin, N. (2004). Pengaruh TIngkat Pendidikan terhadap Pengetahuan Masyarakat tentang Pengobatan Sendiri (Self Medication) di Wilayah Kabupaten Sleman Jogjakarta. Jurnal IImiah Farmasi, 1(2). 